УДК 787.61:7.071.1(8)

DOI https://doi.org/10.31723/2524-0447-2020-30-2-31

\author{
Станіслав Серхійович Жовнір \\ ORCID: 0000-0002-9641-8799
}

аспірант, асистент кафедри музичної україністики

та народно-інструментального мистецтва

Прикарпатського національного університету імені Василя Стефаника szhovnir@gmail.com

\title{
ГІТАРНЕ МИСТЕЦТВО ХХ СТОЛІТТЯ: НАЦІОНАЛЬНІ, РЕГІОНАЛЬНІ І ПЕРСОНАЛЬНІ ПРАКТИКИ
}

У статті пропонується комплексний аналіз історичних етапів та провідних тенденцій розвитку академічного гітарного мистецтва у взаємодії композиторської, виконавської та педагогічної площин, розвитку музично-виразових можливостей гітари, характерних стильових та жканрових особливостей репертуару різних епох, еволюиії техніки гри. Метою статті постає аналіз гітарного мистецтва XX $\mathrm{cm}$. у систематизації здобутків національних, регіональних та персональних практик. Методологія дослідження грунтується на приниипі історизму, фундаментальному для музикознавства, а також на методах системного, порівняльного, описового і культурологічного аналізу. Термінологія дослідження включає назви та поняття, що традиційно застосовуються в музикознавстві, а також специфічні терміни, що існують в гітарному виконавстві та педагогіці. Наукова новизна визначається спробою иілісної, історично простеженої характеристики національних, регіональних та індивідуальних аспектів розвитку гітарного мистецтва упродовж XX століття. Висновки. Встановлено, що формування академічного напряму в гітарному мистецтві відбувалося в різних національних культурах у декількох площинах: конструювання інструмента, композиторська творчість, освітні центри, виконавські школи. Важливу роль у розвитку гітарного академізму відіграли персональні здобутки композиторів і виконавців. Зокрема, активному входженню гітари в академічне музичне мистеитво сприяла творчість митиів-конструкторів, композиторів, виконавців, педагогів як Європи, так і Латинської Америки, зокрема: А. Де Торреса, В. Аріаса, М. Раміреса, Х. Раміреса, I. Флета, А. М. Монтеро, Г. Хаузера, М. Веласкеса. М. Родрігеса, Р. Шнайдера, Ф. Тарреги, М. Понсе, А. Сеговї, А. Барріоса Мангорі, Е. Вілла-Лобоса, Л. Брауера, Е. Пухоля, П.С. Агафошина, О.М. Іванова-Крамського.

Ключові слова: гітарне мистецтво, академічне виконавство, композиторська творчість, конструювання, гітарні школи.

(C) Жовнір C. C., 2020 
Zhovnir Stanislav Serhiiovych, Graduate Student, Assistant at the Department of Musical Ukrainian Studies and Folk Instrumental Art of Vasyl Stefanyk Precarpathian National University

The guitar art of the XX century: national, regional and personal practices

A comprehensive analysis of the historical stages and leading trends in the development of academic guitar art in the interaction of the composer, performing and pedagogical planes, the development of the musical and expressive capabilities of the guitar, the characteristic style and genre features of the repertoire of different eras, he evolution of playing technique is offered in the article. The purpose of the work is analysis of the guitar art of the twentieth century in the systematization of the achievements of national, regional and personal practices. The research methodology is based on the principle of historicism, which is fundamental for musicology, as well as on the methods of systemic, comparative, descriptive and cultural analysis. The research terminology includes names and concepts traditionally used in musicology, as well as specific terms that exist in guitar performance and pedagogy. Scientific novelty is determined by an attempt at a holistic, historically traced characterization of national, regional and individual aspects of the development of guitar art throughout the twentieth century. Conclusions. It has been found that the formation of the academic direction in the art of guitar took place in different national cultures in several dimensions: musical instrument construction, composers oeuvre, educational centers, performing schools. ersonal achievements of composers and performers played an important role in the development of guitar academism. In particular, the active entry of the guitar into academic musical art was facilitated by the creativity of the master designers, composers, performers, teachers from both Europe and Latin America, in particular - A. De Torres, V. Arias, M. Ramirez, J. Ramirez, I. Flat, A. M. Montero, G. Hauser, M. Velazquez. M. Rodriguez, R. Schneider, F. Tarrega, M. Ponce, A. Segovia, A. Barrios Mangori, E. Villa-Lobos, L. Brauer, E. Pujola, P. S. Agafoshin, A.N. Ivanov - Kramskoy.

Key words: guitar art, academic performance, composing, construction, guitar schools.

Жовнир Станислав Сергеевич, аспирант, ассистент кафедры музыкальной украинистики и народно-инструментального искусства Прикарпатского национального университета имени Василия Стефаника

\section{Гитарное искусство XX века: национальные, региональные и персональные практики}

В статье предлагается комплексный анализ исторических этапов и ведущих тенденций развития академического гитарного искусства во взаимодействии композиторской, исполнительской и педагогической плоскостей, развития музыкально-выразительных возможностей гитары, характерных стилевых и жанровых особенностей репертуара разных эпох, эволюции техники игры. Цель статьи - анализ гитарного искусства ХХ в. в систематизации достижений национальных, региональных и персональных практик. Методология исследования основана 
на принципе историзма, фундаментальном для музыковедения, а также на методах системного, сравнительного, описательного и культурологического анализа. Терминология исследования включает названия и понятия, традиционно применяющиеся в музыковедении, а также специфические термины, существующие в гитарном исполнительстве и педагогике. Научная новизна определяется попыткой целостной, исторически прослеженной характеристики национальных, региональных и индивидуальных аспектов развития гитарного искусства на протяжении ХХ века. Выводы. Установлено, что формирование академического направления в гитарном искусстве происходило в разных национальных культурах в нескольких плоскостях: конструирование инструмента, композиторское творчество, образовательные центры, исполнительские школы. Важсную роль в развитии гитарного академизма сыграли персональные достижения композиторов и исполнителей. В частности, активному вхождению гитары в академическое музыкальное искусство способствовало творчество мастеров-конструкторов, композиторов, исполнителей, педагогов как Европы, так и Латинской Америки, в частности: А. Де Торреса, В. Ариаса, М Рамиреса, Х. Рамиреса, И. Флэта, А. М..Монтеро, Г. Хаузера, М. Веласкеса. М. Родригеса, P. Шнайдера, Ф. Тарреги, М. Понсе, А. Сеговии, А. Барриоса Мангори, Э. Вилла-Лобоса, Л. Брауэра, Э Пухоля, П.С. Агафошина, А.Н. Иванова-Крамского.

Ключевые слова: гитарное искусство, академическое исполнительство, композиторское творчество, конструирование, гитарные школы.

Актуальність теми дослідження. В умовах сучасних інтеграційних процесів неабиякий інтерес привертає до себе гітарне мистецтво, що синтезує впливи різних культур, національних та регіональних традицій. Актуальними постають дослідження етномистецьких впливів на розвиток академічного гітарного виконавства та на формування нових стильових тенденцій. Значною є заслуга окремих видатних виконавців та композиторів XX ст., які сформували основний жанровий і тематичний спектр гітарного репертуару, сприяли активному входженню інструмента у сферу академічної музики. Розуміння провідних тенденцій розвитку сучасного українського гітарного мистецтва неможливе без урахування світового досвіду митців та їхнього творчого доробку.

Мета статті - аналіз гітарного мистецтва XX ст. у систематизації здобутків національних, регіональних та персональних практик. При цьому актуалізуються завдання конкретизації мистецьких здобутків композиторів та виконавців для гітари, визначення жанрового кола й аналіз стильових характеристик їх творчості для гітари. 
Наукова новизна визначається спробою цілісної, історично простеженої характеристики національних, регіональних та індивідуальних аспектів розвитку гітарного мистецтва упродовж XX століття, їх впливів на українську гітарну практику.

Виклад основного матеріалу. Достовірно визначити час виникнення інструмента з ознаками гітари вельми важко. Початок поклало вдосконалення, пов'язане з появою шийки (грифу) інструмента, що грала роль «підсилювача міцності» (розвиток цього типу щипкових призвів до появи арфи, псалтеріума, гусел тощо), а потім ладів на грифі. Лише з VIIVIII ст. в Іспанії, куди прототип гітари потрапив через Азію, Асирію та Вавилон, з'являється фідокула («батько» латинської гітари), а потім мавританська гітара. Різниця в прийомах гри на цих інструментах змушує віддати перевагу латинській гітарі як прототипу класичної. До XVI ст. тут існували два іiі різновиди: мавританська, звуки з якої видобувалися щипком, і кастильська, на якій грали акордами. Сучасний інструмент - свого роду гібрид цих інструментів. У XVII ст. гітара стає популярною при королівських дворах - особливо у Англії та Франції. Численні придворні композитори - Франческо Корбетта, Робер де Візе та ін. - внесли вагомий внесок у становлення гітарних жанрів - сонати, тріо-сонати, сюїти, дуетів гітари та голосу.

Гітарне мистецтво до XIX ст. формувалося відособлено від основних тенденцій світової музичної культури - завдяки тому, що сила звуку гітари підходить більше для камерної аудиторії. Не ставши повною мірою академічним, гітарне мистецтво заклало необхідний «репертуарний фундамент» для наступного періоду. У першій половині XIX ст. Діонісіо Агуадо запровадив у широку практику нігтьовий метод звуковидобування та винайшов конструкцію підставки для кріплення нижньої частини мензури, яка використовується й сьогодні. Його друг та співвітчизник Фернандо Сор розширив технічні можливості гітари завдяки широкому використанню прийома барре та інших нововведень.

Гітара набула сучасного виду приблизно у середині XIX ст. завдяки творчим розробкам майстра Антоніо де Торреса. Вона стає глибшою та ширшою. Встановлюється мензура - вібруюча частина струни - 65 см. Трансформувався гриф - він стає більш широким та опуклим відносно деки, продовжується до резонаторного отвору. Встановлюється оптимальна 
кількість (сім) віялових пружин і новий принцип їх розташування [18, с. 63].

У другій половині XIX ст. настав час занепаду гітарного мистецтва. Оперна, симфонічна музика, що досягла свого розквіту, витіснила гітару та затримала iіi розвиток на довгі роки. За влучними словами А. Сеговії, «гітару повісили на стіни перукарень», основним іiі призначенням став примітивний акомпанемент салонним романсам, музиканти перестали сприймати гітару як серйозний інструмент. Багато старих традицій зійшло нанівець, втрачено безліч рідкісних нот та манускриптів, все менше ставало віртуозів, все більше дилетантів.

Іспанія дала початок відродженню гітари, дарувала світові яскраве ім'я композитора, соліста-віртуоза і педагога Франсіско Тарреги (1852-1909). Його новаторська для свого часу техніка гри надихає на творчість його друзів - композиторів: I. Альбеніса, Е. Гранадоса, М. де Фалья та інших. У їхніх фортепіанних творах часто можна почути наслідування гітарі. Таррега створив власну школу гри на гітарі. До його кращих учнів належать Мігуель Льобет, Еміліо Пухоль, Домінико Прат, Даніель Фортеа, Іларіон Лелюп та інші відомі концертанти. На сьогодні всі видані «Школи» Е. Пухоля, Д. Фортеа, Д. Прата, І. Лелюпа, І. Аренса і П. Роча засновані на методі вчення Тарреги [7, с. 64].

Початок XX ст. - це час рішучих змін у розвитку гітарного мистецтва. У всій Європі (за винятком Іспаніі) спостерігається спад інтересу до гітарного мистецтва. Романтична гітара, на якій грали Сміта, Джуліані, себе вже вичерпала, а нова класична гітара, сформована іспанським майстром А. де Торресом у другій половині XIX ст., відповідала новій естетиці, але ще не встигла поширитися по всій Європі. Попри інтерес до гітарного мистецтва з боку європейських композиторів Нової віденської школи, гітара страждає від досить посереднього сольного репертуару. Але поява нового покоління виконавців - учнів і наступників Ф. Тарреги (Н. Любет, Е. Пухоль, А. Сеговія та ін.) сприяє поширенню гітарного мистецтва по всьому світу. Для гітари починають писати багато європейських композиторів, серед яких М. де Фалья, Д. Мійо, Ф. Пуленк, І. Стравінський. Формується особливий гітарний репертуар, основною властивістю якого була опора на фольклор і класико-романтичні традиції [11, с. 106-107]. 
У XX ст. репертуар для гітари істотно розширюється, як за рахунок сучасних творів, написаних спеціально для неї, так і шляхом перекладень для гітари музики попередніх епох. Гітаристи стали грати лютневу музику, сонати і партіти I. С. Баха, твори іспанських і латиноамериканських авторів. У порівнянні з XIX ст. істотно змінилася техніка гри, у зв'язку із чим посилилися іiі динамічні та виразні можливості. Так, справжньою революцією став перехід на нігтьовий спосіб звуковидобування. Звучання гітари посилилося також завдяки вживанню апояндо. Гітаристи стали використовувати темброві можливості інструменту. Змінився підхід до аплікатури лівої руки. Крім того, з'явилася безліч нових прийомів та штрихів, що частково прийшли з народних шкіл, частково з музичного авангарду.

Перші десятиліття XX ст. відкрили ціле сузір'я гітаристів «з великої літери»: Джона Вільямса і Джуліана Бріма, Іду Престі і Олександра Лаго, творчість яких до нині залишається актуальною в гітарному репертуарі.

Андрес Сеговія (1893-1987) - ентузіаст, подвижник гітари, розкриває іiі безмежні можливості. Іспанський гітарист вважається батьком сучасної академічної гітари. Виняткову роль в історії розвитку інструменту відіграли його виконавське, педагогічне дарування та здібності організатора та пропагандиста. М. Вайсборд пише: «Для затвердження гітари як концертного інструмента їй не вистачало того, чим володіли, наприклад, фортепіано або скрипка: високохудожнього репертуару. Історична заслуга Андреса Сеговії і полягає перш за все у створенні такого репертуару» [5]. Під його впливом композитори писали сонати, цикли прелюдій, сюїти, програмні етюди, камерні жанри, концерти для однієї, двох, чотирьох гітар з оркестром. У цих творах яскраво просліджуються класико-романтичні особливості: використання класичних форм, ладо-гармонічного відношення, жанрових канонів (Соната Джіокоза Х. Родріго, Каватина А. Тансмана, Концерт D-dur для гітари з оркестром М. Кастельнуово-Тедеско) орієнтація на програмність музики (сюїта «Замки Іспанії Ф. Морено-Тороби, «Сюїта Компостелана» Ф. Момпу), посилення національних особливостей (використання фольклору своєї країни) - «Гаротін і Солярес» Х. Туріну, Концерт «Аранхуес» Х. Родріго.

Істотний внесок до світової скарбниці гітарного мистецтва зробив Агустін Барріос Мангорі (1885-1944) - геніаль- 
ний парагвайський композитор та гітарист-віртуоз. Він розширив можливості гітари, створив новий вид музики для гітари соло у рамках функціональної гармонії, використовуючи всі шість струн та дев'ятнадцять ладів, чого до нього ніхто ще не досягав. Це можна побачити у записах його «Парагвайського танцю» або «Un sueno de la Floresta». Його етюди тремоло (Un Sueno en la Floresta, Contemplacion и Una Limosna рог el Amor de Dios) розвивають цей вид техніки ще більше в порівнянні, наприклад, зі «Спогадами про Альгамбру» Ф. Тарреги [3].

Класично-романтичні традиції - не єдине, що стало характерним для гітарної музики $30-40-\mathrm{x}$ років XX століття. На цей час прийшовся розквіт одного з найбільш своєрідних iii напрямків - латиноамериканської музики, у якій зливається американська та нова іспанська гітара, що стало перспективою появи нових творчих здобутків. Своєрідність та унікальність латиноамериканської музики - у синтезі культур трьох різних материків: Америки, Свропи та Африки. Такого феномену немає більше ніде у світі. Яскравими представниками латиноамериканської музики є К. Густавино, Х. Кордосо, Х. Марель, А. Хінастера, А. Пьяцолла, Е. Фалю, Р. Лара, M. Торес, К. Тіра та ін. Їхня музика особливо популярна серед виконавців сучасності завдяки своїй демократичності та яскравій фольклорній основі.

У сфері бразильської гітарної музики, заснованої на традиціях фольклору, працювало багато талановитих композиторів: Пернамбуко, Бонфа, Альмейда та ін., які використовували у своїх творах ритми bossa nova i samba, що дало новий поштовх творчим пошукам у США та Європі. Бразильські та кубинські композитори кращі роки своєї творчості провели на території Західної Європи, тому їх музика справедливо може називатися європейською.

Один із найвідоміших бразильських композиторів Ейтор Вілла-Лобос (1887-1959) - засновник національної композиторської школи, ініціатор створення та президент Бразильської академії музики. Найбільш характерною рисою його творчості стало використання народних форм та жанрів, популяризація бразильського фольклору. Він також розробив власну систему музичного виховання дітей. Майже всі гітарні твори написані під впливом А. Сеговії та присвячені йому. Серед найважливіших - Концерт для гітари у супроводі орке- 
стру (1952), який вперше виконав саме А. Сеговія у Парижі, два цикли - 5 прелюдій та 12 етюдів, 2 «Шоро», численні мініатюри [14, с. 101-122].

Мануель Понсе (1882-1948) - мексиканський композитор та педагог, майстер художньої стилізації. На його творчість сильно вплинули гармонія та форма традиційних мексиканських пісень. Писав музику для інструментів соло, для камерних ансамблів та оркестрів. Найбільш відомі його гітарні твори: Sonata mexicana (1925), Тһиme variй et Finale (1926), Sonata III (1927), Sonata clбsica (1928), Sonata romontica (1929), Suite en la Mineur (1929), Variations and Fugue on «La Folia» (1929), Valse (1937), Sonatina meridional (1939), Variations on a Theme of Cabezyn (1948) [9].

У другій половині XX ст. гітара повністю включається до академічної культури. Її почали використовувати у всіх експериментальних течіях другої хвилі авангарду 50-70-х років: Концерт для гітари з оркестром «Три графіки» Моріса Охани, «Адаптовані гітари I і II» Гарі Пратча, «Пісні, гудіння, рефрени смерті» Дж. Крумба та ін. Нове покоління віртуозів 80-90-х років довело техніку гри до раніше недосяжного рівня. Лідерство належить італійській школі (К. Маріконе, А. Дезидеріо, Ф. Платіно). В Америці - М. Барруеко та брати Ассад, у Німеччині - Т. Хопшток, в Англії - Д. Рассел. В основі творчості композиторів нового покоління лежить нове розуміння синтезу епох, стилів, напрямків, культур, світосприйняття. Це характерно як для гітарної музики, так і для академічної музики в цілому. Серед таких творів - Подвійний концерт для гітари і сітара К. Домініконі, Концерт для гітари 3 оркестром «Метіс»Р. Дієнса.

Значне, особливе місце серед гітаристів-композиторів другої половини ХХ ст. посідає кубинець Лео Брауер (1939). Брауер починав із фламенко, пізніше вчився класичному стилю у I. Ніколи, а також музиці епохи Відродження у Е. Пухоля у Свропі. Створив музику до більш ніж 50 фільмів, написав для гітари «П'єсу без назви», Прелюд, «Характерний танець», 5 легких етюдів, Три концертних танця для гітари та оркестру струнних інструментів, Концерт для гітари, Para sonar a dos для гітари та магнітофону, Canticum для гітари, «Тарантас» у стилі фламенко. Завдяки йому американська гітара остаточно вийшла за рамки фольклорного інструменту та здобула статус повноцінного академічного інструменту [9]. 
XX століття відкриває нові школи гітари, нові імена віртуозів-педагогів. Еміліо Пухоль (1886-1980) - іспанський (каталонський) класичний гітарист, виконавець на віуелі, композитор і видатний педагог. Зацікавився класичною гітарою, почувши виконання Франціско Тарреги, і протягом семи років брав у нього уроки. У протилежність Андресу Сеговії, що грав нігтями, Пухоль дотримувався техніки Тарреги, що вважав за краще видобувати звук подушечками пальців, досягаючи м'якшого, але і більш обмеженого по тембру звучання. У віці 60 років він став професором гітари і віуели в консерваторіях Барселони і Лісабона.

У своїй «Школі гри на шестиструнній гітарі» Еміліо Пухоль формулює ті нові принципи, які внесли до гітарного виконання іспанські гітаристи Ф. Таррега і Е. Льобет [15]. Перш за все, це стосується звукових можливостей гітари: широке вживання апояндо дозволило інструменту звучати голосніше. Крім того, значно розширилися технічні засоби гітари, i, внаслідок цього, розширився гітарний репертуар. Саме завдяки заслугам іспанської школи, гітара в двадцятому столітті стає концертним інструментом.

Його принципи гри багато в чому відрізняються від класичної італійської гітарної школи ХІХ століття. Перш за все, це стосується звуковидобування. У італійців основний прийом для пальців іта - тірандо, тобто щипок. Пухоль вже 3 перших вправ учить грати з опорою, тобто використовувати прийом апояндо. Водночас великий палець у італійців грає 3 опорою на сусідню струну, застосовуючи апояндо, тоді як представники іспанської школи для великого пальця правої руки використовують тірандо. На наш погляд, сучасний гітарист повинен рівною мірою володіти двома цими способами [4].

Петро Агафошин (1874-1950) - російський гітарист, один iз перших педагогів та виконавців на шестиструнній гітарі. Акомпанував видатним співакам - Ф.І. Шаляпіну, Д. Смирнову, Т. Руффо. Брав участь у виконанні опери Массне «Дон Кіхот» у 1916 році, де акомпанував Шаляпіну. Неодноразово зустрічався $з$ Андресом Сеговією, який мав на нього великий вплив, надихнувши на необхідні корективи у постановку та прийоми гри. Сеговія назвав Агафошина кращим московським гітаристом. Під враженням від спілкування з іспанським гітаристом Агафошин написав книгу «Новое о гитаре», 
видану у 1928 році [1]. Агафошин вів курси гітари та викладав у Московській консерваторії, видав понад десять збірників п’єс класиків шестиструнної гітари та шість альбомів власних транскрипцій та композицій

Створив «Школу гри на шестиструнній гітарі», що стала першим у СРСР фундаментальним методичним посібником [2]. Основними методичними положеннями якої стали:

1. Учень повинен пройти основні етапи, які пройшла сама гітара в їі історичному розвитку, ознайомитися з прийомами та техніками гітаристів різних стилів та епох.

2. Учень повинен навчатися грі не на сухому учбово-тренувальному матеріалі типу вправ та етюдів, а на вміло підібраному високомистецькому матеріалі, що виховує смак та приносить не тільки практичні та технічні навичка, але й естетичне задоволення від навчання.

3. Основний сенс існування гітари, за переконанням автора, полягає у ліричності, задушевності, чистоті та красі звуків. Гітарі не личить бравурність, форсування звуку [4].

Олександр Іванов-Крамськой $\quad(1912-1973)$ - видатний гітарист, композитор, диригент, педагог, автор «Школи гри на шестиструнній гітарі», учень Агафошина. Акомпанував I.C. Козловському та Н.А. Обуховій. Диригував Ансамблю пісні й танцю, Народному хору та оркестру народних інструментів на головному радіо. Автор п’єс та двох концертів для гітари з оркестром. Завдяки йому гітара стала професійним інструментом, іiі стали викладати у середніх та вищих музичних закладах не тільки у Росії, а й на пострадянському просторі. На його честь проводиться щорічний Московський міжнародний фестиваль гітарної музики імені О.М. Іванова-Крамського [6, с. 20-30].

Не можна не згадати й про майстрів із виготовлення музичних інструментів, оскільки удосконалення гітари створило підгрунтя для розвитку технічних і художніх можливостей інструмента. Для XX століття характерні два принципово нових явища. По-перше, стилістичне та інструментально-виконавське новаторство, пов'язане з відходом від традиційних прийомів композиторського письма, вимагає від майстрів музичних інструментів збагачення технічних та виразних можливостей гітари. На світ з'являються нові види гітар, лиш віддалено схожих з більш давніми взірцями. По-друге, нові течії як у музичних стилях, так і в галузі кон- 
струкції інструмента віднині зароджуються не у Європі, а в Америці [18, с. 65].

Першість у виготовленні класичних інструментів досі утримують іспанці. Завдяки діяльності Антоніо де Торреса наприкінці XIX - початку XX століття головним центром виготовлення концертних гітар стає Мадрид. Тут працюють видатні майстри: Вісенте Аріас, Мануель та Хосе Рамірес, які виховали ціле сузір'я чудових майстрів. Барселона також залишається важливим центром, тут працює Ігнасіо Флета, чиї інструменти привертають увагу великих виконавців. Видатна школа майстрів є й у Гренаді, найбільш відомий - Антоніо Марин Монтеро [18, с. 68].

Чимало видатних гітаристів творчо працюють і в інших країнах: Герман Хаузер (ФРН), Робер Буше (Франція), Давид Рубіо та іспанець Хосе Романільос (Англія), Мануель Веласкес, Мануель Родрігес, Ріхард Шнайдер (США). Шнайдер, учень мексиканця Хуана Піменталя, намагається використовувати точні акустичні розрахунки, що веде до використання незвичайних форм пружин, підставок, всього корпуса. Хосе Рамірес та Нарсісо Йєпес конструюють десятиструнну гітару з додатковими басовими струнами, що звучать нижче Е (великої октави).

Водночас молоді майстри створюють копії старовинних інструментів «Vieux-Paris» для більш точного виконання репертуару бароко. Росте попит на фабричні гітари, виробництво яких переноситься у країни Далекого Сходу. Тут першість за «Хонда» (Корея) «Ямаха», «Аріа», «Кохно», «Темікура» (Японія), які витісняють відомі фірми ФРН та Італії. Проте гітари ручної роботи продовжують купляти у іспанців (класичні та фламенко) та США (джаз та фолк) [18, с. 74-75].

Сучасне гітарне мистецтво України також активно розвивається в руслі новітніх тенденцій європейської класичної гітарної школи. Гітарні композитори поєднують здобутки європейської, латиноамериканської та національної музики. Значну дослідницьку роботу проводила В. Сидоренко, яка здійснювала збір, транскрипцію та видавництво творів, написаних для гітари соло такими композиторами, як М. Скорик, С. Станкович, В. Камінський, О. Щетинський, К. Цепколенко та інші. Крім того, варто згадати сучасних українських композиторів М. Стецюна та А. Золкіна, які написали «Іспанський концерт» та «Концерт № 1» для гітари з оркестром відповідно. 
Також потрібно зауважити, що в Україні у 2000 році створена Асоціація гітаристів (очолювана К. Чеченею), яка $\epsilon$ структурним підрозділом Національної всеукраїнської музичної спілки. Асоціація гітаристів НВМС регулярно проводить концерти, майстер-класи, семінари, творчі вечори відомих українських та зарубіжних виконавців: «Гітарні перспективи», «Світ гітари», концерти талановитих гітаристок «Пані гітара», всеукраїнські та міжнародні фестивалі гітарного мистецтва (В. Петренка, «Осінні фарби», пам'яті К. Смаги, «Київ» та ін.) Потрібно відзначити, що в Україні є професійні гітарні ансамблі, найбільш відомі 3 яких «Flame», «Бєльканто», «Фієста», а також квартет гітаристів при Національній філармонії України (Київ) [8, с. 18-27].

В історії гітарного мистецтва України можна виділити імена багатьох видатних корифеїв. Костянтин Смага (1912-1985) один із піонерів вітчизняної класичної гітари, видатний віртуоз і педагог. Працював над транскрипціями класичних творів для гітари, обробками народних і популярних пісень. Автор серії нотних збірок: «Українські народні пісні», «П'єси для шестиструнної гітари», «Сучасні пісні в перекладенні для шестиструнної гітари» та ін. Серед найвідоміших вихованців К. Смаги - В. Вільгельмі, С. Зайцев. Л. Косатова, С. Колесник, Л. Колесникова, Г. Любимов, В. Манілов. О. Мітрошин, С. Самоткін, I. Степанов. Методичні поради К. М. Смаги сприяли розвитку виконавської майстерності I. Кузнецова, В. Петренка, П. Полухіна, А. Шпакова, С. Крахмальникова, В. Осинського та інших відомих музикантів [17].

Анатолій Шевченко (1938-2012), гітарист-віртуоз, композитор, музикознавець, лауреат міжнародних конкурсів, автор книг з історії фламенко, безлічі монографічних та авторських концертних програм, які дають можливість ознайомитися 3 усіма стилями та напрямками - від давньогрецької кіфаристики до сучасного авангарду. Серед його творів - «Музика при свічах» (класицизм та модерн), «Музика Еллади», програма «Бах та сучасність», «Думи мої» (як акомпанемент поезії Тараса Шевченка) [19].

Валерій Петренко (1939) - гітарист-віртуоз, учень Іванова-Крамського, випускник Львівської консерваторії, композитор, перший в історії нашої країни гітарист - народний артист України (1999). Акомпанував співакам Ю. Гуляєву, А. Солов’яненко, М. Кондратюку. Перший вітчизняний виконавець кон- 
церту «Аранхуес» Х. Родріго. Автор програми «Театр Валерія Петренко» - першого у світі Театру гітари. [16].

Микола Михайленко (1952), гітарист-віртуоз, педагог, лауреат Всеукраїнського конкурсу. Видав повний цикл Хрестоматій для ДМШ, вокальні збірники з акомпанементом гітари. Автор ряду перекладів для гітари популярних мелодій і танців, редактор-укладач репертуарних збірників для ДМШ. Автор багатьох п’єс, обробок, етюдів, монографії «Довідник гітариста», підручника «Методика викладання гри на гітарі» (Київ-2003 р). Працював з М. Кондратюком, К. Столяром, Н. Петренко-Матвійчук [11].

Лео Вітошинський (1941-2008) - австрійський гітарист-віртуоз українського походження. Учень Сеговії та Йєпеса, лауреат міжнародних конкурсів, професор Університету міста Грац (Австрія). Педагог, кавалер «Великого ордена за заслуги перед Республікою Австрія». Лео Вітошинський - нащадок інтелігентного українського роду з Галичини. Активно сприяв розвиткові австро-українських культурних зв'язків. Заснував премію молодим музикантам. Почесний професор Львівської державної музичної академії ім. М.В. Лисенка, заслужений артист України (2001). Входив у склад журі престижних міжнародних конкурсів. Автор книги «Cantabile e ritmico. Про мистецтво гри на гитарі» [13].

Висновки. Таким чином, становлення академічного напряму в гітарному мистецтві відбувалося в декількох площинах розвитку: конструювання інструмента, композиторська творчість, методичні видання, навчальні центри, виконавські школи в різних національних культурах. Можна сказати, що в XIX столітті була закладена серйозна професійна база для того стрімкого стрибка, який стався в XX столітті, коли гітара стала інструментом академічним і концертним.

У XX столітті репертуар для гітари істотно розширився, як за рахунок сучасних творів, написаних спеціально для неї, так і шляхом аранжування для гітари музики попередніх епох. Істотно змінилася техніка гри, з'являються нові прийоми гри, що частково прийшли з народних шкіл, частково 3 музичного авангарду. Головними характерними рисами цього розвитку стали асиміляція різних стилів та напрямів, кристалізація нової музичної мови, нових принципів композиції, формоутворення, формування різних естетичних платформ, у т.ч. і на основі технічного вдосконалення інструмента. 


\section{СПИСОК ЛІТЕРАТУРИ}

1. Агафошин П.С. Новое о гитаре. Москва : Госиздат. Музыкальный сектор, 1928. 60 с.

2. Агафошин П.С. Школа для шестиструнной гитары. 2-е издание. Москва : Искусство. 1938. 207 с.

3. Агустин Барриос Мангоре (Agustin Pio Barrios). Офіційний сайт Н. Болдирєва. URL : http://boldyrev.net/guitarclass/st_barrios.htm.

4. Александрова М. Обзор гитарных школ. URL : http://gitarist.by/ guitar-schools-obzor/.

5. Вайсборд М. Андрес Сеговия и гитарное искусство XX века. Москва, 1989. 208 с.

6. Вайсборд М. Об А. М. Иванове-Крамском. Дань почтения гитаре. Очерк второй. Музыкальная жизнь. № 4. 1988. С. 29-30.

7. Вольман Б. Гитара и гитаристы: очерк истории шестиструнной гитары. Ленинград : Музика, 1968. С. 25-70.

8. Гітара в Україні. Асоціація гітаристів Національної всеукраїнської музичної спілки. № 1. 2008. С. 18-27.

9. Лео Брауер. Гитаристы и композиторы. URL : http://www. abc-guitar.narod.ru/pages/brouwer.htm

10. Мануель Понсе. Гитаристы и композиторы. URL: http://www. abc-guitar.narod.ru/pages/ponce_mm.htm.

11. Михайленко Н.П. Гитаристы и композиторы. URL : http:// www.abc-guitar.narod.ru/pages/mikhaylenko.htm.

12. Отюгова Т., Галембо А., Гурков И. Рождение музыкальных инструментов. Ленинград : Музыка, 1986. С. 106-107.

13. Петров И. Профессор Витошинский и венские украинцы. Сегодня. 22.04.99.

14. Пичугин П. Эйтор Вилла Лобос и бразильская национальная музыкальная культура. Культура Бразилии. Москва : Наука, 1981. C. $101-122$.

15. Пухоль Э. Школа игры на шестиструнной гитаре. Москва : Сов. композитор, 1978. 189 с.

16. Савицкая O. Гитары многоцветная палитра. URL : http:// gazeta.zn.ua/CULTURE/gitary_mnogotsvetnaya_palitra.html.

17. Смага К. Гитаристы и композиторы. URL : http://www. abc-guitar.narod.ru/pages/smaga.htm.

18. Шарнассе Е. Шестиструнная гитара от истоков до наших дней. Москва : Музыка, 1991. С. 61-75.

19. Шевченко А. Гитаристы и композиторы. URL : http://www. abc-guitar.narod.ru/pages/shevtschenko.htm.

\section{REFERENCES}

1. Agafoshin P.S. (1928). New about the guitar. M.: Gosizdat. Music sector. [in Russian]

2. Agafoshin P.S. (1938). School for six-string guitar. 2nd edition. Moscow: Art. [in Russian] 
3. Agustin Barrios Mangore (Agustin Pio Barrios). Official site of N. Boldyrev: URL: http://boldyrev.net/guitarclass/st_barrios.htm [in Ukrainian]

4. Alexandrova M. Review of guitar schools. URL: http://gitarist.by/ guitar-schools-obzor/ [in Russian]

5. Weisbord M. (1989). Andres Segovia and the guitar art of the twentieth century. M. [in Russian]

6. Vaysbord M. (1988). About A. M. Ivanov-Kramskoy. A tribute to the guitar. The second sketch. Music life. No. 4. [in Russian]

7. Volman B. (1968). Guitar and guitarists: an outline of the history of the six-string guitar. L.: Muzyka. [in Russian]

8. Guitar in Ukraine (2008). Guitarists Association of the National All-Ukrainian Music Union. № 1. [in Ukrainian]

9. Leo Brower. Guitarists and Composers. URL http://www. abc-guitar.narod.ru/pages/brouwer.htm [in Russian]

10. Manuel Ponce. Guitarists and Composers. URL: http://www. abc-guitar.narod.ru/pages/ponce_mm.htm [in Russian]

11. Mikhailenko N.P. Guitarists and Composers. URL: http://www. abc-guitar.narod.ru/pages/mikhaylenko.htm [in Russian]

12. Otyugova T., Galembo A., Gurkov I. (1986). The birth of musical instruments. L.: Music. P. 106-107. [in Russian]

13. Petrov I. (1999). Professor Vitoshinsky and Viennese Ukrainians. Today. 22.04. [in Russian]

14. Pichugin P. (1981). Heitor Villa Lobos and the Brazilian national musical culture. Brazilian culture. Moscow: Nauka. P. 101-122. [in Russian]

15. Puhol E. (1978). School of playing a six-stringed guitar. M.: Sov. Composer. [in Russian]

16. Savitskaya O. Guitars a multicolor palette. URL: http://gazeta. zn.ua/CULTURE/gitary_mnogotsvetnaya_palitra.html [in Russian]

17. Smaga K. Guitarists and Composers. URL: http://www.abc-guitar. narod.ru/pages/smaga.htm [in Russian]

18. Sharnasse E. (1991). Six-string guitar from the beginnings to the present day. M.: Music. C. 61-75. [in Russian]

19. Shevchenko A. Guitarists and Composers. URL: http://www. abc-guitar.narod.ru/pages/shevtschenko.htm [in Russian] 